\title{
Gender and Criminal Victimization in Barbados
}

\author{
David Achanfuo Yeboah*,1 and Farley Brathwaite ${ }^{2}$
}

${ }^{1}$ Queensland Health, Brisbane, QLD, Australia; ${ }^{2}$ University of the West Indies, 44 Paradize Heights, St. James, Barbados

\begin{abstract}
The interrelationship between gender and criminal victimization has been well document in the literature for various jurisdictions around the globe. This article examines these interrelationships for Barbados, and provides a synthesis of evidence to support the general notion in the literature that gender is related to fear of crime, types of crime and impact of criminal victimization. The study found that gender was a very good predictor of fear of crime, criminal 1 victimization and the impact of crime, while explaining substantial proportions in the variance in those variables. The study concludes that differences in criminal victimization and gender exist in Barbados and that the gender of victims determines their fear of crime as well as the impact of criminal victimization.
\end{abstract}

Keywords: Gender, crime, victimization, barbados.

\section{INTRODUCTION}

This paper explores some aspects of gender and criminal victimization in Barbados by examining the relationship between gender as a demographic variable, and selected indicators of criminal victimization. More specifically, this paper examines gender differences in fear of crime, type of victimization and the physical, economic, emotional impact of criminal victimization.

This study focuses on Barbados where the prevalence of crime is very high and where no previous study of this kind and scale has been undertaken.

Gender in criminal victimization has been well documented in mainstream victimology globally, but not in Barbados in particular and the wider Caribbean generally. While there has been some work on fear of crime (Brathwaite, 2004; Chadee, 2003;) and levels of crime (Yeboah, 2002), not much is available on the interrelationships between gender and criminal victimization in Barbados, hence the relevance of this study. Gender has been mentioned here and there in various Caribbean studies, such as Brathwaite, 2004; Brathwaite \& Yeboah, 2004, Chadee, 2003, Harriot, 2003, Yeboah, 2002, but the point of departure of this study from the existing literature is the specific investigation of the links between gender and criminal victimization in Barbados.

The interrelationships between gender and criminal victimization have been analyzed at two main levels. One approach has tended to focus specifically on the victimization experiences of women through an analysis of women as victims of crimes such as rape, sexual assault, and domestic violence, or what Morash (2006) has referred to as gender related victimizations. This approach has provided detailed insights into the extent, the nature, the causes, and

*Address correspondence to this author at the Queensland Health, Australia, 2/9 Naver St., Middle Park, QLD 4074, Australia; Tel: +61 73715 8063; Mobile: +61 439244 437; E-mail: dkyeboah@hotmail.com the consequences of victimization among female victims of sexual crimes. The second approach has tended to focus on gender as a differentiating factor in the victimization process by comparing the nature, the circumstances, and the experiences of criminal victimization among men and women (Chadee, 2003; Ditton Bannister, Farrali, \& Gilchrist, 1999). This Barbados study focuses on the second approach by attempting to examine and establish gender variations in criminal victimology.

This choice may be justified by the argument of Bowker (1979) that the focus on the sexual differentiation should lead to a focus on the total victimization experiences of women, rather than analyzing their ceremonial victimization experiences exclusively. An added advantage of this approach is that it offers comparative insights between men and women, and between their experiences across different crime types and, in relation to Barbados and perhaps the wider Caribbean, these insights are lacking in the literature. There is research evidence that women are more likely than their male counterparts to express a fear of crime (Ditton $e t$ al., 1999) and, writing about Trinidad, Chadee (2003: p. 75) noted that "the literature has consistently shown sex as a predictor of fear of crime". The study attempts to find out if these observations are also true for Barbados, given the high level of crime in that country.

There is a convergence of thought within the existing research literature that women are far less likely to be victims of crime than men (Brathwaite \& Yeboah, 2004; Chadee, 2003; Mayhew, Aye Maung, \& Mirrlees- Black, C. 1993; Schmallenger, 1999;). For example, Miethe \& McCorkle (1998) demonstrated that men were far more likely to be victims of violent crimes such as homicide, aggravated assault, and robbery, women were more likely than men to be victims of rape, and spousal abuse, and that female headed households were more likely to be victims of motor vehicle theft. The existing research evidence shows further that men are more likely to be victimized by strangers, while women are more likely to be victimized by persons who they know (Bureau of Justice Statistics, 1991 p. $53)$. 
The impact of crime on the victim has been examined in the research literature in three main areas, namely physical, economic and psychological impacts (Yeboah and Brathwaite, 2007). The existing evidence, by and large, points to a higher risk of physical injury among females than males and, where physical injuries are received, they tend to be more serious among females than they are among males (see Laub, 1990). With respect to the economic consequences of victimization, there is no clear evidence on gender variations.

Evidence from the existing research literature indicates that the psychological impact of crime may be more devastating and more enduring than the physical and economic effects (Resick, 1990; Lurigio \& Resick, 1990; Ben-David \& Avni, 1995; Brathwaite, 2004). The psychological Impact has been measured on indicators such as fear, anxiety, suicidal ideation, sexual dysfunction, diminished self esteem and depression (Lurigio \& Resnick, 1990), feelings of vulnerability, unpleasant thoughts, upset stomach (Lurigio,1987), and post-traumatic stress disorder in the form of intrusive memories and dreams (Kilpatrick, Saunders, Veronen, Best, \& Von, 1987).

There is an array of evidence alluding to the view that women are generally more distressed by crime than men (Brathwaite, 2004; Chadee, 2003; Harriot, 2003), and that emotional problems, difficulty in sleeping and feeling unsettled were more likely to be reported by females than by males (Harriot, 2003; Walklate, 1989). However, there is some contradictory evidence that the male female differences in this regard are not automatic (Ben-David \& Avni, 1995), that the effects may be short term (Resick,1990), and that the ultimate psychological outcomes of criminal victimization may depend on a number of factors including the nature of victim-offender relationships (Kilpatrick, Saunders, Veronen, Best, \& Von, 1987).

\section{THE PRESENT STUDY}

The purpose of this article is to examine gender differences in criminal victimization in Barbados following some of the themes discussed in the introduction. More precisely it examines gender differences in fear of crime, type of crime and the physical, economic, and the emotional impact of criminal victimization by addressing the following research questions

1. Do the types of reported crime vary by gender?

2. What is the level of fear of crime, and do Barbados men and women perceive fear of crime differently?

3. Are there gender variations in terms of the physical, economic and emotional impact of crime in Barbados?

4. Is gender a strong predictor of fear of crime and type of victimization?

5. Is gender a strong predictor of the physical, economic and psychological/emotional impact of victimization?

\section{Data and Methods}

The data for the study come from the responses of the survey participants and the daily crime reports which are maintained by the Royal Barbados Police Force. The main methodology is the survey of victims of crime involving the administration of a pre-designed questionnaire to randomly selected respondents. The instruments used in the survey were developed so as to collect, analyze and report information on the physical, economic and psychological costs to the victims as well as the factors which influenced their experiences. A number of variables were used in the study including type of crime, injuries and other physical impacts, property and monetary losses, and emotional difficulties.

The respondents were contacted in person at the addresses in the police records and by phone where possible ( 85 per cent of homes in Barbados have telephones). Face to face interviews were conducted because it allowed for the collection of detailed information and, together with the Police records, provided a very good source of information for the study.

\section{Dependent and Independent Variables}

Fear of crime was the dependent variable in the first logistic regression model, while type of criminal victimization was the dependent variable in the $2^{\text {nd }}$ regression model. Physical impact, economic impact and psychological impact were the dependent variables in the $3^{\text {rd }}$, $4^{\text {th }}$ and $5^{\text {th }}$ regressions models respectively. Gender, age, education and employment remained the independent variables in all the regression models..

The use of correlation, $\chi^{2}$ and related regression analysis threw more light on the interrelationships between crime and gender and enhanced our understanding of those relationships in Barbados. To avoid multi-colinearity and ensure that no substantial confounding or spurious effects existed, a tolerance test was undertaken for the independent variables and acceptable values of .691, .652, .711, and .711 were obtained for gender, age, education and employment respectively. This means that multiplecorrelation with other variables is low and that the possibility of multi-collinearity is limited. These values further corroborate the correlations and $\chi^{2}$ values reported in this study.

\section{Sample}

A total of 5,162 crime victims aged fifteen years and over reported crimes against them to the Barbados Police Force in 1998 and 1062 victims were randomly selected. Many of these 1062 victims no longer lived at the address they had given to the Police, and the study, therefore, focused on the 458 respondents who were located at the addresses in Police records. The sample remained random because the final 458 respondents were part of the initial 1062 respondents selected randomly from the police records.

It must also be emphasized that the sample of 458 victims used in this study did not include crimes against tourists/visitors. Tourists were excluded from the sampling frame and study because of logistic issues including the fact that they had left the country and could not be contacted. The victims in the study were mainly males ( 55.2 percent), from the older (thirty years and over) age group (63.3 percent), of post primary education levels (83.6 percent), of single/never married marital status (63.5 percent), employed (69.4 percent), about evenly distributed among first time victims (49.6 percent) and those who have previously been victims of crime (50.4 percent). 


\section{FINDINGS}

Many variables were used in the study and (Table 1) points to moderate statistically significant correlations among gender, types of criminal victimization, fear of crime, impact of criminal victimization and the other study variables. These interrelationships are also confirmed by the $\chi^{2}$ tests.

\section{Type of Criminal Victimization by Gender}

The single largest crime perpetrated against males was burglary, as distinct from assault for females. Over 35\% of male respondents were victims of burglary compared with $6.6 \%$ for females, while over $23 \%$ of female respondents were victims of assault compared with $17.5 \%$ for males. Burglary was closely followed by theft (28.8\%), and robbery (21.1\%) for males, while for females, assault was followed by robbery $(17.5 \%)$ and theft $(17.1 \%)$, So that, for both male and female victims, there was a convergence on robbery and theft (ranked $2^{\text {nd }}$ and $3^{\text {rd }}$ for each). A statistically significant $\chi^{2}$ of $15.133(\mathrm{sig}=.000)$ was obtained for gender and criminal victimization, corroborating the evidence from the correlations that the two variables were related.

Gender explained $51.3 \%$ of the variance in criminal victimization in the bivariate analysis The stepwise regression results in Table $\mathbf{2}$ show that the marginal effect of gender on criminal victimization was strong, evidenced in the $\mathrm{R}^{2}$ change of $34.3 \%$ when gender is added to the model equation. Gender was a good predictor of criminal victimization, making the largest unique statistically significant contribution of $.498(\mathrm{sig}=.000)$ to the prediction of criminal victimization, compared with age (beta .112, sig= .000 ), education (beta, 313, sig $=.001$ ) and employment (beta .189 , sig= .013).

\section{Fear of Crime by Gender}

Over $91 \%$ of male victims and $90.4 \%$ of female victims reported that crime was a major problem indicating that they were afraid of crime (Table 3). About $67 \%$ of male victims and $68.2 \%$ of female victims were afraid of being burglarized. Other indicators of fear of crime, which scored highly with victims in this study, included fear of being assaulted (61.3\% males and $67.3 \%$ for females), and fear of being robbed (60.2\% males and $66 \%$ for females). Over half of the female victims and slightly under half of the male victims indicated that they were afraid of being raped, while comparatively lower proportions of both male and female victims reported feeling unsafe in their homes and neighborhoods.

Gender explained $49.6 \%$ of the variance in fear of crime. The $\mathrm{R}^{2}$ change was $29.1 \%$ when gender was entered in the $1^{\text {st }}$ regression model, and this was statistically significant. This means further that gender had a marginal effect of $29.1 \%$ on fear of crime. As indicated in the regression coefficients in Table $\mathbf{4 b}$, gender made the largest unique statistically significant contribution of $-.543(\mathrm{sig}=.000)$ to the prediction of fear of crime, compared with age (beta.053 , sig $=.001$ ), education (beta, .123 , sig $=.000$ ) and

Table 1. Correlations Among the Variables in the Study

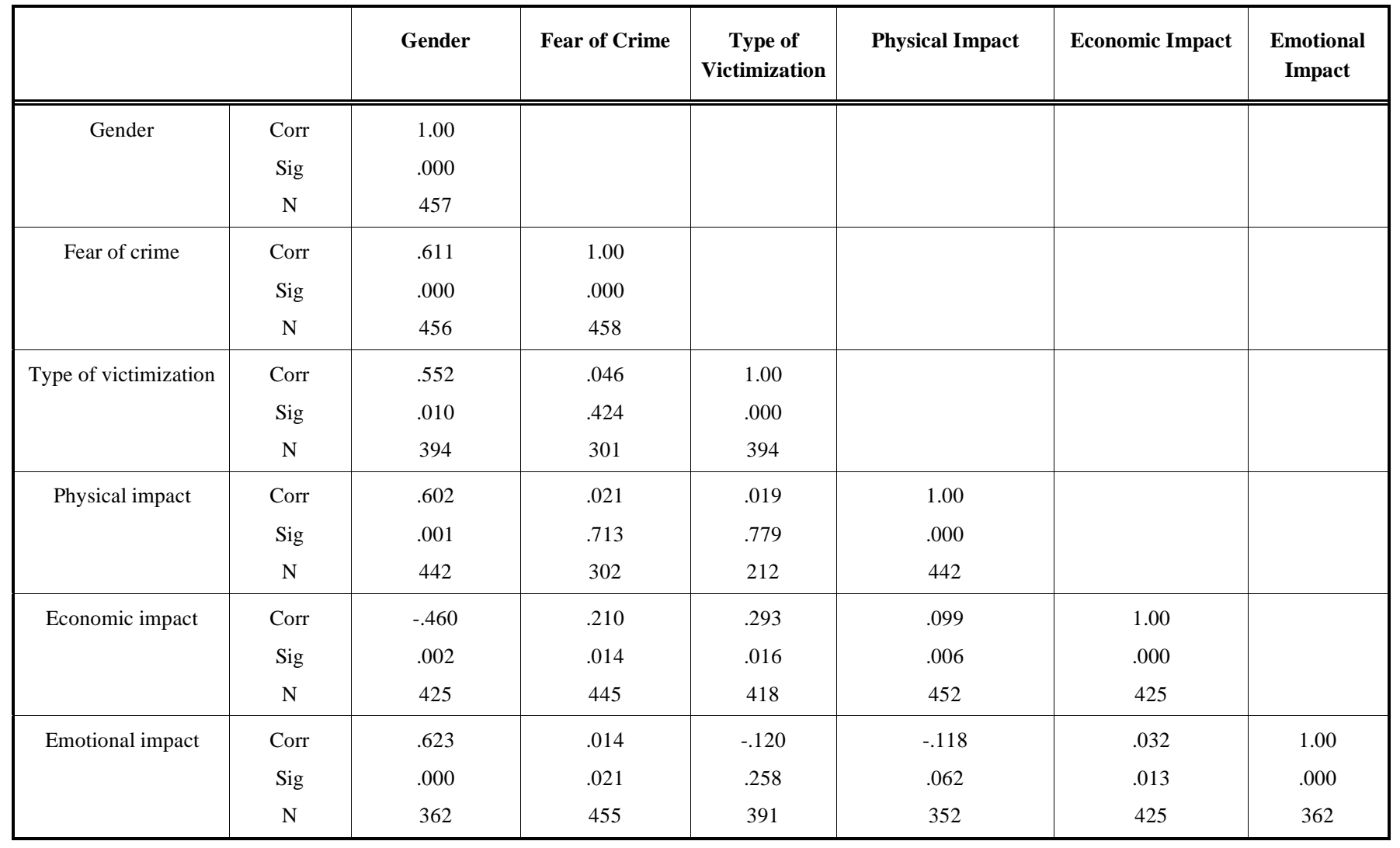

Source: Regression analysis. 
Table 2a. Gender and Type of Victimization - Stepwise Regression Model Results

\begin{tabular}{|c|c|c|c|c|}
\hline Model & R Square & Adjusted R Square & R Square Change & Std. Error of the Estimate \\
\hline \hline Age & $.12 \mathrm{p}$ & .118 & .031 & 1.30 \\
\hline Education & .151 & .148 & .009 & 1.44 \\
\hline Employment & .160 & .157 & .243 & 1.37 \\
\hline Gender & .513 & .510 & & \\
\hline
\end{tabular}

Table 2b. Gender and Type of Victimization - Stepwise Regression Coefficients

\begin{tabular}{|c|c|c|c|c|}
\hline Model & \multicolumn{2}{|c|}{ Unstandardized Coefficients } & Standardized Coefficients & Beta \\
\hline \hline & B & Std Error & & .000 \\
\hline Constant & 50.091 & 1.011 & .112 & .000 \\
\hline Age & .115 & .045 & .313 & .001 \\
\hline Education & .322 & .017 & .189 & .013 \\
\hline Employment & .196 & 1.771 & .498 & .000 \\
\hline Gender & .502 & .081 & & \\
\hline
\end{tabular}

Source: Regression analysis

employment (beta .221 , sig= .213). Beta values have been used instead of the usual B values because the beta values are standardized, converting the values of the different variables to the same scale. With a $\chi^{2}$ of $22.110(\mathrm{sig}=.000)$, there is a relationship between gender and fear of crime in Barbados.

\section{Impact of Criminal Victimization by Gender}

The study assessed the gender differences in the impact of criminal victimization at three levels, namely impact of physical injury, economic impact and psychological impact.

\section{Physical Impact}

Over half of the respondents indicated that they had received physical injuries, with females $(55.1 \%)$ being more likely to do so than males $(50.9 \%)$. Of these a massive $77.8 \%$ of the male victims and $76.4 \%$ of their female counterparts needed medical care, while $71.4 \%$ (male) and $35.7 \%$ (females) reported being hospitalized for 1-3 days. Gunshot wounds and fracture were the least reported physical injuries for both male and female victims.

With an $\mathrm{R}^{2}$ change of $49.1 \%$ when gender is included in the model, the effect of gender on physical impact of

Table 3. Fear of Crime by Gender of Victims

\begin{tabular}{|c|c|c|c|}
\hline & \multicolumn{2}{|c|}{ Gender } \\
\hline \hline Victims who: & Male & Female & Total Population \\
\hline Said that crime was a major problem & $91.1(214)$ & $90.4(170)$ & $90.8(384)$ \\
\hline Felt unsafe in their neighborhood at nights & $14.2(35)$ & $37.1(73)$ & $24.3(108)$ \\
\hline Felt unsafe in their homes at nights & $8.4(21)$ & $68.2(63)$ & $18.5(84)$ \\
\hline Were afraid of being burglarized & $67.6(167)$ & $66.0(132)$ & $67.9(304)$ \\
\hline Were afraid of being robbed & $60.2(150)$ & $54.0(101)$ & $62.8(282)$ \\
\hline Were afraid of being raped & $47.0(108)$ & $67.3(134)$ & $50.1(209)$ \\
\hline Were afraid of being assaulted & $61.3(152)$ & $40.5(64)$ & $64.0(286)$ \\
\hline Were afraid of having their motor vehicles stolen & $35.7(75)$ & $37.8(139)$ \\
\hline
\end{tabular}

*Number of respondents in brackets

Source: Survey data 
Table 4a. Gender And fear of Crime - Stepwise Regression Model Results

\begin{tabular}{|c|c|c|c|c|}
\hline Model & R Square & Adjusted R Square & R Square Change & Std. Error of the Estimate \\
\hline \hline Age & .111 & .108 & .048 & 2.09 \\
\hline Education & .159 & .157 & .045 & 1.23 \\
\hline Employment & .204 & .201 & .291 & 1.71 \\
\hline Gender & .496 & .494 & & $2 . .27$ \\
\hline
\end{tabular}

Table 4b. Gender and Fear of Crime - Stepwise Regression Coefficients

\begin{tabular}{|c|c|c|c|c|c|}
\hline Model & \multicolumn{2}{|c|}{ Unstandardized Coefficients } & Standardized Coefficients & Sig & Collinearity \\
\hline \hline & B & Std Error & Beta & .000 & .001 \\
\hline Constant & 121.111 & 1.811 & .053 & .000 & .652 \\
\hline Age & .105 & .045 & .123 & .213 & .711 \\
\hline Education & .115 & .417 & .000 & .711 \\
\hline Employment & .201 & .177 & -.543 & .691 \\
\hline Gender & & & & .500 \\
\hline
\end{tabular}

Source: Regression analysis.

victimization appeared strong (Table 5b), showing a marginal effect of over $49 \%$. In addition, gender made the largest statistically significant contribution of -.443 ( $\mathrm{sig}=$ .000) to the prediction of physical impact, compared with age (beta .105 , sig $=.001$ ), education (beta, 123, sig $=.002$ ) and employment (beta $.301, \mathrm{sig}=.002)$. A $\chi^{2}$ value of 13.415 was obtained for gender and physical impact of victimization and this was statistically significant $(\mathrm{sig}=.001)$.

\section{Economic Impact}

For medical expenses, $36.4 \%$ and $42.9 \%$ of male and female victims respectively reported spending up to $\$ 99$ on medical bills as a result of the victimization. The proportions of victims who reported spending over $\$ 100$ on medical bills following the victimization were $63.3 \%$ for males and $57.1 \%$ for females. Apart from value of items taken under $\$ 500$, the proportion of male and female victims reporting items taken at various value levels were more or less the same. Clear gender differences exist in relation to days lost from work, with $63.8 \%$ of male victims reporting up to 1 week loss compared with only $27.8 \%$ of female victims, and $72.2 \%$ of female victims reporting 1 week or more working time lost compared to $36.5 \%$ for their male counterparts.

Gender explained about $40 \%$ in the variance in economic impact of criminal victimization. However, the stepwise regression results revealed that the marginal effect of gender was comparatively limited, evident in the $\mathrm{R}^{2}$ change of only $18.1 \%$. Gender made the $2^{\text {nd }}$ largest statistically significant contribution of $.344(\mathrm{sig}=.000)$ to the prediction of economic impact of criminal victimization, compared with age (beta .223 , sig $=.001$ ), education (beta, .146 , sig $=.001$ ) and employment (beta $.401, \operatorname{sig}=.000$ ). The study found a $\chi^{2}$ of $15.112(\mathrm{sig}=.000)$ confirming the existence of a relationship between gender and the economic impact of criminal victimization in Barbados (see also Yeboah and Brathwaite, 2007).

\section{Psychological Impact}

The psychological impact of criminal victimization is investigated by examining the emotional difficulties suffered by victims, using a number of selected indicators. The single indicator acknowledged by the largest proportion of victims was anger, $62.7 \%$ and $69.7 \%$ for male and female respondents respectively. Other emotional difficulties included shock $(33.5 \%$, males; $44.6 \%$, females), feelings of vulnerability $(25.9 \%$, males; $37.9 \%$, females) and self blame (23.2\%, males; $22.3 \%$, males). For male victims, the least reported emotional difficulties included suicidal feelings (1.2\%), upset stomach $(2.8 \%)$, and social withdrawal $(2.8 \%)$ while, for female victims, suicidal feelings $(6.7 \%)$, bad dreams $(6.9 \%)$ and upset stomach $(8.2 \%)$ were least reported.

Gender explained $52.7 \%$ of the variance in psychological impact of criminal victimization. Table 7a shows further that the marginal effect of gender on the psychological impact of criminal victimization was over $35 \%$. Table $\mathbf{7 b}$ shows that gender made the largest single statistically significant contribution of .524 ( $\mathrm{sig}=.000)$ to the prediction of psychological impact, compared with age (beta .053, sig= .001 ), education (beta, 123, sig $=.000$ ) and employment (beta .021 , sig= .324). A $\chi^{2}$ of 25.190 ( $\left.\mathrm{sig}=.000\right)$ was also obtained, confirming the relationship between gender and the psychological impact of criminal victimization. in this Barbados study. 
Table 5a. Gender and Physical Impact - Regression Results

\begin{tabular}{|c|c|c|c|c|}
\hline Model & R Square & Adjusted R Square & R Square Change & Std. Error of the Estimate \\
\hline \hline Age & .153 & .151 & .008 & 2.08 \\
\hline Education & .161 & .158 & .042 & 2.41 \\
\hline Employment & .203 & .198 & .491 & 3.02 \\
\hline Gender & .203 & .199 & & 2.16 \\
\hline
\end{tabular}

Table 5b. Gender and Physical Impact: Regression Model Coefficients

\begin{tabular}{|c|c|c|c|c|}
\hline Model & \multicolumn{2}{|c|}{ Unstandardized Coefficients } & Standardized Coefficients & Sig \\
\hline \hline & B & Std Error & Beta & .000 \\
\hline Constant & 95.010 & 1.022 & -.443 & .000 \\
\hline Gender & -.456 & .007 & .105 & .001 \\
\hline Age & .115 & .105 & .123 & .002 \\
\hline Education & .104 & .125 & .301 & .002 \\
\hline Employment & .299 & 1.311 & &. \\
\hline
\end{tabular}

Source: Regression analysis.

Table 6a. Gender and Economic Impact - Regression Results

\begin{tabular}{|c|c|c|c|c|}
\hline Model & R Square & Adjusted R Square & R Square Change & Std. Error of the Estimate \\
\hline \hline Age & .188 & .185 & .013 & 1.04 \\
\hline Education & .201 & .198 & .228 & 1.38 \\
\hline Employment & .429 & .427 & .181 & 1.23 \\
\hline Gender & .610 & .601 & 1.11 \\
\hline
\end{tabular}

Table 6b. Gender and Economic Impact: Regression Model Coefficients

\begin{tabular}{|c|c|c|c|c|}
\hline Model & \multicolumn{2}{|c|}{ Unstandardized Coefficients } & Standardized Coefficients & Beta \\
\hline \hline & B & Std Error & & .000 \\
\hline Constant & 113.115 & 1.903 & .344 & .000 \\
\hline Gender & .335 & 1.11 & .223 & .001 \\
\hline Age & .228 & .145 & .401 & .001 \\
\hline Education & .153 & 0.01 & .000 \\
\hline Employment & .417 & & & .4 \\
\hline
\end{tabular}

Source: Regression analysis

\section{DISCUSSION AND CONCLUSION}

The incidence and prevalence of crime in Barbados is high, but no study of this kind has previously been undertaken (not even in the wider Caribbean). The study throws more light on the interrelationships between gender and fear of crime, criminal victimization and the impact of crime. Both the bivariate and stepwise regressions showed that gender had a strong effect on the types of victimization, fear of crime and the physical, economic, and psychological impacts of criminal victimization. Gender explains more 
Table 7a. Gender and Psychological Impact - Regression Results

\begin{tabular}{|c|c|c|c|c|}
\hline Model & R Square & Adjusted R Square & R Square Change & Std. Error of the Estimate \\
\hline \hline Age & .108 & .106 & .054 & 3.11 \\
\hline Education & .162 & .159 & .014 & 2.14 \\
\hline Employment & .176 & .173 & .351 & 2.44 \\
\hline Gender & .527 & .524 & & 2.09 \\
\hline
\end{tabular}

Table 7b. Gender and Psychological Impact: Regression Model Coefficients

\begin{tabular}{|c|c|c|c|c|}
\hline Model & \multicolumn{2}{|c|}{ Unstandardized Coefficients } & Standardized Coefficients & Sig \\
\hline \hline & B & Std Error & Beta & .0 .00 \\
\hline Constant & 40.115 & 1.811 & .524 & .001 \\
\hline Gender & .528 & .099 & .053 & .000 \\
\hline Age & .078 & .045 & .123 & .000 \\
\hline Education & .434 & .017 & .021 & .324 \\
\hline Employment & .038 & 2.04 & & \\
\hline
\end{tabular}

Source: Regression analysis.

than half the variance in types of criminal victimization and showed marginal effects in the stepwise regressions.

While the findings were generally consistent with some of the results of previous studies, new insights were provided by the study. The study findings were consistent with the literature in the sense that they supported the general notion of gender variations in criminal victimization. This Barbados study showed clear differences in fear of crime and type of victimization by gender as well as the impact of crime. Another salient finding, which was consistent with the literature, was that gender predicted strongly the physical and emotional impact of criminal victimization (see, for example, Kilpatrick, Saunders, Veronen, Best, \& Von, 1987; Lurigio, \& Resick, 1990), Departing from the literature, gender was found to have a weaker effect on the economic impact of criminal victimization

The combination of correlations, $\chi^{2}$ and related regression analysis provided insights on Barbados which are not available in the research literature. The study concludes that gender differences exist in criminal victimization in Barbados, and that a relationship exists between the gender of victims and fear of crime, criminal victimization and the impact of the victimization. These are important observations because they suggest that there may be continuities and similarities in the impact of criminal victimization by gender across societies with different cultures and at different levels of development and locations.

This study, the first formal study of victims of crime to be conducted in Barbados, offers a number of other important insights. Firstly, the combination of official statistics with survey data made available a diverse range of data, helping to overcome the problem of memory lapse commonly associated with retrospective victimization studies. The benefits of such a combination can be reaped by other researchers through replication. Secondly, the study provides some hitherto unavailable baseline data on how male and female victims of crime in Barbados experience their victimization, identifying gender differences. Finally, the focus of this study on gender and criminal victimization across a range of crimes and characteristics enhanced more detailed analysis of gender variations in criminal victimization than is usually available in the literature. This approach makes it possible to identify the specific areas of difference, and the specific areas of similarity in the victimization experiences of females and males.

\section{REFERENCES}

Ben-David, B., \& Avni, N. (1995). Victims in israel: post victimization effects of property crimes, In Singh, S., Makkar, B., \& .Friday, P. (Eds.). Global perspectives in victimology, Jalandh, India: ABS Publications,

Block, K., \& Skogan, W. (1986). Resistance and non fatal outcomes in stranger to stranger predatory crimes. In Violence and victims, vol. 1, (pp. 241-253).

Bowker, R. (1979). The criminal victimization of women. Victimology: An International Journal, 4(4), 371-374.

Brathwaite, F. (2004). Victims of crime in Barbados. In A. Harriot, \& F. Brathwaite, (Eds.). Crime and criminal justice in the Caribbean. (pp. 87-128). Kingston: Arawak Publications.

Brathwaite, F., \& Yeboah, D. (2004). Victims of crime in the Criminal Justice System in Barbados. Journal of Criminal Justice, 32(2), 431-442.

Bureau of Justice Statistics. (1991). Criminal victimization in the United States, US Department of Justice, Washington, DC.

Chadee, D. (2003). Fear of crime and risk victimization. Social and Economic Studies, 52(1), 70-97.

Ditton, J., Bannister, J, Gilchrist, E., \& Farrall, S. (1999) Afraid or Angry? Recalibrating the fear of crime. International Review of Victimology, 6(2), 83-89.

Harriot, A. (2003). Fear of criminal victimization in a reputedly violent environment. Social and Economic Studies, 52(1), 35-72. 
Kilpatrick, D., Saunders, B., Veronen, L., Best, C., \& Von, J. (1987). Criminal Victimization: Lifetime prevalence, reporting to police, and psychological impact. Crime and Delinquency, 33, 479-489.

Laub, J. (1990). Patterns of criminal victimization in the United States. In Lurigio, A., Skogan, W., \& Davis, R. (Eds.). Victims of crime: problems, policies, and programs. CA: Sage Publications.

Lurigio, A. (1987). Are victims all alike? The adverse, generalised, and differential impact of crime. Crime and Delinquency, 33, 452-467.

Lurigio, A., \& Resick, P. (1990). Healing the psychological wounds of criminal victimization: predicting the post-crime distress and recovery. In Lurigio, A., Skogan, W., \& Davis, R. (Eds.). Victims of crime: problems, policies, and programs. CA: Sage Publications.

Mayhew, P., Maung, A. P., \& Mirrlees-Black, C. (1993). The 1992 British Crime Survey. Home Office Research Study No. 132. London, Home Office.
Miethe, T., \& McCorkle, R. (1998). Crime profiles- the anatomy of dangerous persons, places and situations. Los Angeles: Roxbury Publishing.

Morash, M. (2006). Understanding gender, crime, and justice. Thousand Oaks, California: Sage Publications.

Resick, P. (1990). Victims of sexual Assault. In Lurigio, A., Skogan, W., \& Davis, R. (Eds.). Victims of crime: problems, policies, and programs. CA: Sage Publications.

Schmallenger, F. (1999). Criminology today: an integrative introduction. New Jersey: Prentice Hall.

Walklate, S. (1989). Victimology: The victim and the criminal justice process. London: Unwin Hyman.

Yeboah, D.A. (2002). Crime and its solutions in Barbados. Journal of Criminal Justice, 30(5), 409-416.

Yeboah, D.A., \& Brathwaite, F.S. (2007). The nature and impact of criminal victimization in Barbados. Journal of Ethnicity in criminal Justice, 5(2/3), 55-77.

(C) Yeboah and Brathwaite; Licensee Bentham Open.

This is an open access article licensed under the terms of the Creative Commons Attribution Non-Commercial License (http://creativecommons.org/licenses/by-nc/3.0/) which permits unrestricted, non-commercial use, distribution and reproduction in any medium, provided the work is properly cited. 